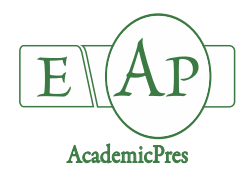

Csorba V et al. $(2020)$
Notulae Botanicae Horti Agrobotanici Cluj-Napoca 48(2):770-782
DOI: $10.15835 /$ nbha48211873
Research Article

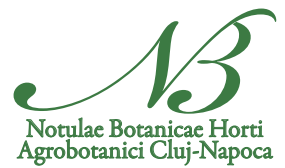

\title{
Cultivar and year effects on the chemical composition of elderberry (Sambucus nigra L.) fruits
}

\section{Virág CSORBA ${ }^{1 *}$, Magdolna TÓTH ${ }^{2}$, Anna M. LÁSZLÓ³, Levente KARDOS ${ }^{4}$, Szilvia KOVÁCS 5}

\author{
${ }^{I}$ Szent István University, Department of Pomology, 29-43, Villányi út, Budapest, \\ Hungary; virgyy@gmail.com (*corresponding author) \\ ${ }^{2}$ Almakúti Ltd., 0171/21 hrsz., Zalaszántó, Hungary; dr.toth.magdolna@t-online.hu \\ ${ }^{3}$ Szent István University, Department of Biometrics and Agrarinformatics, 29-43, Villányi út, Budapest, \\ Hungary; Laszlo.Anna@kertk.szie.hu \\ ${ }^{4}$ Szent István University, Department of Soil Seince and Water Management, 29-43, Villányi út, Budapest, \\ Hungary;Kardos.Levente@kertk.szie.hu \\ ${ }^{5}$ Research Institute for Fruitgrowing and Ornamentals, National Agricultural Research and Innovation Centre, Budapest, \\ Hungary; kovacs.szilvia@fruitresearch.naik.hu
}

\begin{abstract}
Due to their outstanding anthocyanin content, elderberries are mainly used in the food industry to produce pigment concentrations. Thanks to the increase in demand, elderberry is grown on ever greater areas in Hungary and in neighbouring countries. Cultivar use, however, is very one-sided, being practically restricted to 'Haschberg'. As this cultivar has many negative properties, growers have begun to plant and test new cultivars. When determining the commodity value of cultivars, it is important to examine not only the physical traits of the fruit, but also their main chemical parameters. In the present experiment the chemical properties (soluble solids and titratable acid content, total polyphenol and anthocyanin content, antioxidant capacity) of the fruit of 11 elderberry cultivars ('Haidegg 13', 'Haidegg 17', 'Haschberg', K3, 'Korsör', 'Samdal', 'Samidan', 'Samocco', 'Sampo', 'Samyl', 'Weihenstephan') were analysed in three consecutive years. In addition to the comparative evaluation of the cultivars, this work also aimed to discover correlations between the components and to study the effect of the year on the chemical composition of the fruit. Significant differences were found between the cultivars for the soluble solids content $(\mathrm{F}(10 ; 8.74)=9.71 ; \mathrm{p}=0.001)$, the titratable acid content $(\mathrm{F}(10 ; 22)=7.91 ; \mathrm{p}<0.001)$, the polyphenol content $(\mathrm{F}(10 ; 22)=9.77 ; \mathrm{p}<0.001)$, the anthocyanin content $(\mathrm{F}(10 ; 8.52)=36.18 ; \mathrm{p}<0.001)$ and the antioxidant capacity $(\mathrm{F}(10 ; 22)=3.61 ; \mathrm{p}=0.006)$. A year effect was proved for the water-soluble solids content $(\mathrm{F}(2 ; 30)=4.02 ; \mathrm{p}=0.028)$ and the antioxidant capacity $(\mathrm{F}(2 ; 30)=5.21 ; \mathrm{p}=0.011)$. Among the chemical properties, a significant positive linear correlation was only detected between the polyphenol and anthocyanin contents $(r=0.91 ; \mathrm{p}<0.001)$. Among the cultivars, 'Sampo', 'Samidan' and 'Weihenstephan' exhibited outstanding polyphenol and anthocyanin contents. The soluble solids content and antioxidant capacity of 'Haidegg 17 ' were also promising.
\end{abstract}

Keywords: anthocyanins; antioxidant activity; polyphenols; soluble solids; titratable acidity

Received: 06 Apr 2020. Received in revised form: 12 Jun 2020. Accepted: 17 Jun 2020. Published online: 30 Jun 2020. 


\section{Introduction}

As the result of changes in eating habits, attention has increasingly moved to fruit and vegetables with high pigment contents that could be used to replace artificial food colourings (Wissgott and Bortlik, 1996). Elderberry (Sambucus nigra L.) has been used as a medicinal plant for hundreds of years, but its cultivation area has increased greatly over the last few decades, thanks to its diverse uses and easy production (Charlebois et al., 2010). Elderberries have exceptionally high anthocyanin content compared to other fruit species (602.9-1265.3 mg CGE $100 \mathrm{~g}^{-1} \mathrm{FW}$ ) (Veberic et al., 2009). The dark red pigment concentration extracted from the berries is used as a colouring for squashes, jams and other products of plant origin (Charlebois et al., 2010).

Apart from anthocyanins, the fruit also contain numerous other bioactive compounds, the health benefits of which have been reported by many authors (Netzel et al., 2005; Knudsen and Kaack, 2015; Mlynarczyk et al., 2018). The berries have significant vitamin $\mathrm{C}$ content (26-36 $\left.\mathrm{mg} 100 \mathrm{~g} \mathrm{~g}^{-1}\right)$, and among the minerals the quantity of potassium, calcium and magnesium is considerable (Vulic et al., 2008). The

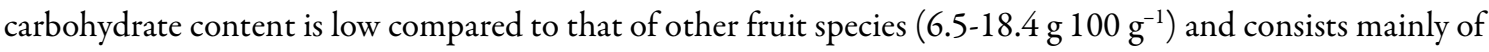
simple sugars (glucose and fructose) (Veberic et al., 2009). The titratable acid content is low to medium, and citric acid is the main organic acid $\left(0.6-1.7 \mathrm{mg} 100 \mathrm{~g}^{-1}\right)$, though there is also a substantial quantity of malic acid (Kaack et al., 2008). Foodstuffs prepared from elderberries have notable antioxidant capacity $(5.04-6.37 \mathrm{mmol}$ $100 \mathrm{~g}^{-1}$ ) (Akbulutu et al., 2009; Cejpek et al., 2009).

The 'Haschberg' cultivar is widely grown in the major elderberry-producing countries in Europe (Austria, Denmark, France, Hungary and Germany). In order to eliminate the problems caused by the uneven ripening and disease susceptibility of 'Haschberg' and by the fact that the production of a single cultivar leads to a short harvesting and processing season, increasing emphasis is now laid on the breeding of cultivars specifically for the food industry and on the comparative evaluation of cultivars (Kollányi et al., 2005; Möhler et al., 2009; Matejicek et al., 2015; Thomas et al., 2015).

In addition to papers on the chemical traits of American cultivars (Sambucus canadensis L.) (Özgen et al., 2010; Perkins-Veazie et al., 2015; Wu et al., 2015), many authors have also reported differences in the chemical composition of the fruit of a number of European cultivars originating from Sambucus nigra (Kaack and Austed, 1998; Lee and Finn, 2007; Möhler et al., 2009; Veberic et al., 2009; Fejer et al., 2015). In Hungary the first analyses of chemical components and the determination of optimum harvesting dates were performed on 'Haschberg' (Stéger-Máté et al., 2002; Stefanovitsné, 2004), while later these studies were extended to include the cultivars 'Sampo' and 'Samocco' (Szalóki-Dorkó et al., 2015). Similar comparative evaluations on the chemical parameters of other European cultivars with promise for cultivation have not yet been carried out.

However, the chemical composition of the fruit is not only determined by genetic factors. Environmental and climatic factors also influence fruit composition, which thus exhibits a diverse chemical profile each year (Salvador et al., 2015). The effect of internal and external factors on the fruit composition of American cultivars has been proved by Thomas et al. (2013) for American cultivars and by Ferreria et al. (2020) for the European cultivars 'Sabugueiro', 'Sabugueira' and 'Bastardeira', but to the best of our knowledge no paper has yet dealt with the effect of climatic factors on the chemical components of major European elderberry cultivars.

In the present experiment the chemical parameters of 11 elderberry cultivars were evaluated in three consecutive years. Measurements were made on the soluble solids content, the titratable acidity, the antioxidant capacity and the polyphenol and anthocyanin contents of fruit picked at the optimum harvesting date. The results were statistically analysed to discover whether the year and the genotype influenced the given parameters and whether there were any interactions between individual chemical traits. The three years of data made it possible to compare the cultivars and to select genotypes with better chemical properties than 'Haschberg'. 


\section{Materials and Methods}

\section{Plant material}

Fruit samples were picked at the Experimental and Research Farm of Szent István University (SZIE) in Soroksár in three consecutive years $(2017,2018,2019)$. After removing the stalks, the fruit of the 11 cultivars evaluated ('Haidegg 13', 'Haidegg 17', 'Haschberg', K3, 'Korsör', 'Samdal', 'Samidan', 'Samocco', 'Sampo', 'Samyl', 'Weihenstephan') was homogenised and stored at $-25^{\circ} \mathrm{C}$ until required. Sample preparation and chemical measurements were then performed at the Department of Pomology (SZIE). Prior to spectral measurements, the frozen fruit pulp was thawed and centrifuged for $10 \mathrm{~min}$ at 15,000 rpm in a Hettich Mikro $22 \mathrm{R}$ laboratory centrifuge. Absorbance was then recorded using a Hitachi U-2800A spectrophotometer.

\section{Determination of soluble solids content and titratable acidity}

The soluble solids content (SSC) of the fruit was analysed using an HI 96801 digital refractometer. The titratable acid (TA) content was determined on the basis of the Hungarian standard (MSZ EN 12147:1998). Fruit samples weighing $10 \mathrm{~g}$ were made up to $100 \mathrm{ml}$ with distilled water, after which they were titrated with $0.1 \mathrm{M}$ sodium hydroxide $(\mathrm{NaOH})$ solution in the presence of dimidium bromide-disulphine blue until the colour changed. The total acid content was expressed as citric acid equivalents and the results were given as $\mathrm{w} / \mathrm{w} \%$.

\section{Determination offerric reducing antioxidant power (FRAP)}

The antioxidant capacity of elderberries was determined using the FRAP method described by Benzie and Strain (1996). The FRAP method involves the reduction of $\mathrm{Fe}^{3+}$ ions to $\mathrm{Fe}^{2+}$, which in turn form a bluecoloured complex with 2,4,6-tripyridyl-S-triazine (TPTZ). The intensity of the colour depends on the antioxidant concentration. Absorbance was measured at $593 \mathrm{~nm}$. Antioxidant capacity was defined as ascorbic acid equivalents ( $\mathrm{mmol} \mathrm{AAE} 100 \mathrm{~g}^{-1} \mathrm{FW}$ ) based on the ascorbic acid standard calibration curve.

\section{Determination of total polyphenol content (TPC)}

TPC was measured according to the method of Singleton and Rossi (1965) with slight modifications. Samples weighing $500 \mu \mathrm{l}$ were placed in test-tubes, to which $2.5 \mathrm{~cm}^{3}$ Folin-Ciocalteu's reagent and $7.5 \mathrm{~cm}^{3}$ sodium carbonate (20\%) were added. After 2 hours, the absorbance of each sample was measured at $760 \mathrm{~nm}$. The calibration curve was made using gallic acid. The results were expressed as micrograms of gallic acid equivalents on a fresh weight basis (mg GAE $100 \mathrm{~g}^{-1} \mathrm{FW}$ ).

\section{Determination of total anthocyanin content (TAC)}

Total anthocyanin content (TAC) was determined using ethanol and hydrochloric acid, as described by Füleki and Francis (1968). Samples weighing $0.1 \mathrm{~g}$ were taken from the supernatant obtained after centrifugation. After the addition of $0.2 \mathrm{ml}$ conc. $\mathrm{HCl}$, the samples were made up to $10 \mathrm{ml}$ with $96 \%$ alcohol. After 30 minutes in the dark, the absorbance was measured at $510 \mathrm{~nm}$. The results were expressed as milligrams of cyanidin-3-glucoside equivalents on a fresh weight basis (mg Cy3G $100 \mathrm{~g}^{-1} \mathrm{FW}$ ).

\section{Meteorological data in the years of the experiment}

The meteorological data used to evaluate the year effect were taken from the www.metnet.hu website for the $23^{\text {rd }}$ district of Budapest. The precipitation distribution differed greatly in the three years (Figure 1). The largest quantity of precipitation was recorded in $2018(710 \mathrm{~mm})$ and the smallest in $2019(687 \mathrm{~mm})$, with $709 \mathrm{~mm}$ in 2017 . The mean annual temperature was highest in $2019\left(13.5^{\circ} \mathrm{C}\right)$ and lowest in $2017\left(12.3^{\circ} \mathrm{C}\right)$. 


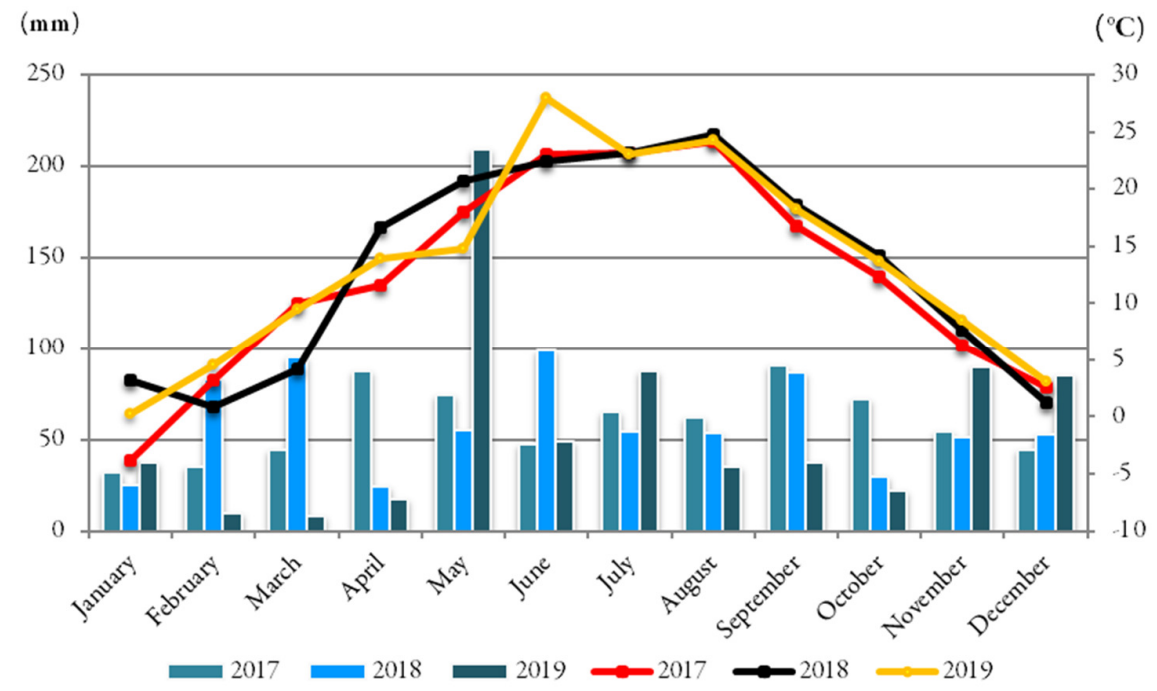

Figure 1. Mean monthly precipitation and temperature (Soroksár) (www. metnet.hu)

\section{Statistical methods}

Three technical replicates were measured each year for each cultivar (from the same pooled sample), and these were then averaged. The data were analysed using one-way ANOVA models (Dobson, 2002; Hang, 2014), and the model residuals were checked for normality using the Kolmogorov-Smirnov test and graphical representations of distribution (histogram, QQ plot). Pairwise comparisons were made using the Sidak p-value adjustment. Levene's tests were run to check the homogeneity of variances. If there was significant heteroscedasticity, Welch's ANOVA and the Games-Howell post hoc test were applied. Homogeneous subsets were labelled on mean and standard deviation plots for each variable. Linear relationships between pairs of investigated variables were analysed using Pearson's correlation and scatterplots. Statistical analysis was performed with IBM SPSS (Version 25, IBM Corporation, Armonk, NY, USA), where p-values of $<0.05$ were considered to indicate statistical significance. Plots were generated in Excel (Microsoft Office 365).

\section{Results and Discussion}

\section{Soluble solids content (SSC)}

The soluble solids content is one of the most important quality parameters for elderberries, as it determines their market value. The processing industry will only buy up fruit with a soluble solids content of at least 12\% (Sidor and Gramza-Michalowska, 2015). This criterion was met for all the genotypes tested, with the exception of 'Sampo', 'Samyl' and 'Weihenstephan' (Figure 2). The SSC values varied between 10.8 and $14.56 \%$, which is within the range previously reported by Csorba et al. (2019) and Kaack et al. (2005). The SSC value was lowest for 'Sampo' in two of the years, confirming the findings of Safránková (2011). SzalókiDorkó et al. (2015), however, reported that the SSC level of 'Sampo' was similar to that of the other cultivars tested. The present data showed outstandingly high values for 'Korsör' in two years, somewhat contradicting the findings of Lee and Finn (2007). According to Kaack (1997) the SSC value of 'Haschberg' is considerably lower than that of other cultivars, but this too was not confirmed in the present work. The most promising cultivars were found to be 'Haidegg 17' and 'Korsör', together with the experimental Hungarian genotype K3. The statistical analysis of the three-year data confirmed that the cultivar exerts an influence on the soluble solids content $(\mathrm{F}(10 ; 8.74)=9.71 ; \mathrm{p}=0.001)$. 


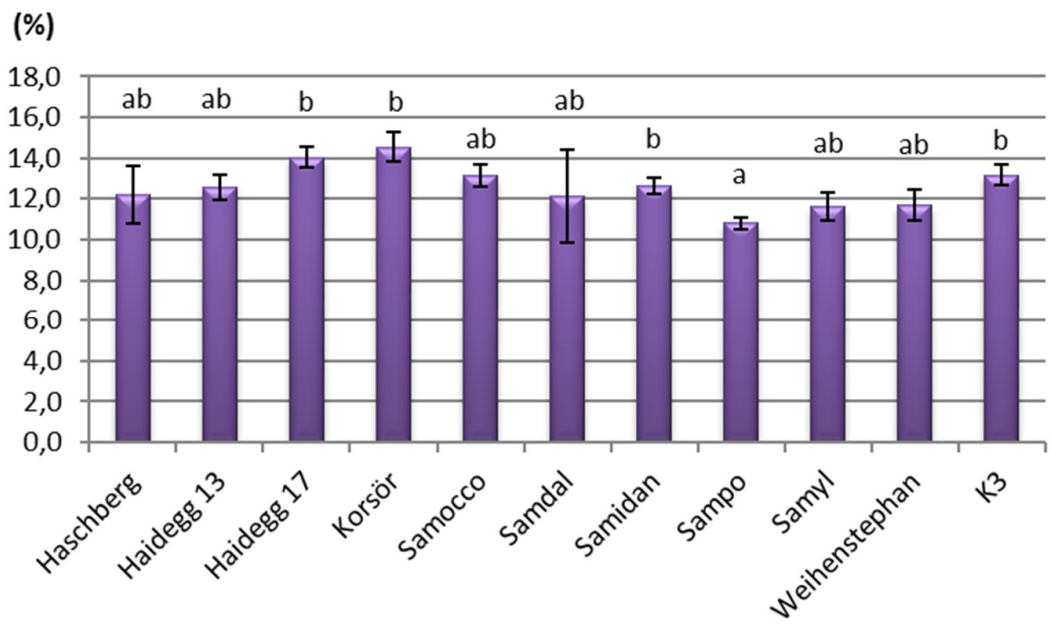

Figure 2. Mean values of soluble solids content in the fruit of different elderberry cultivars. Different letters indicate significant differences between the values (Sidak test, $\mathrm{p}<0.05$ )

\section{Titratable acidity (TA)}

Quantitative changes in the acids, and especially in their ratio compared to the sugar content, influence the flavour. The combined data for the three years showed the lowest titratable acidity for 'Samocco' and K3, while the highest value was exhibited by 'Samidan' in two years and by 'Sampo' in one year (Figure 3). The data recorded for 'Sampo' and 'Samocco' are in agreement with those of Kaack (1997). However, Kaack and Knudsen (2015) found lower TA values for 'Samyl' than for 'Samdal', in contradiction to the present findings. According to Szalóki-Dorkó (2016) 'Samocco' had higher acid content than 'Haschberg', which was not confirmed in the present study. The acid content of 'Haschberg' proved to be the lowest of all the cultivars tested by Safránková (2011), which again contradicted the present data. The statistical evaluation of the data proved the significant effect of the cultivar on the mean titratable acidity $(F(10 ; 22)=7.91 ; \mathrm{p}<0.001)$.

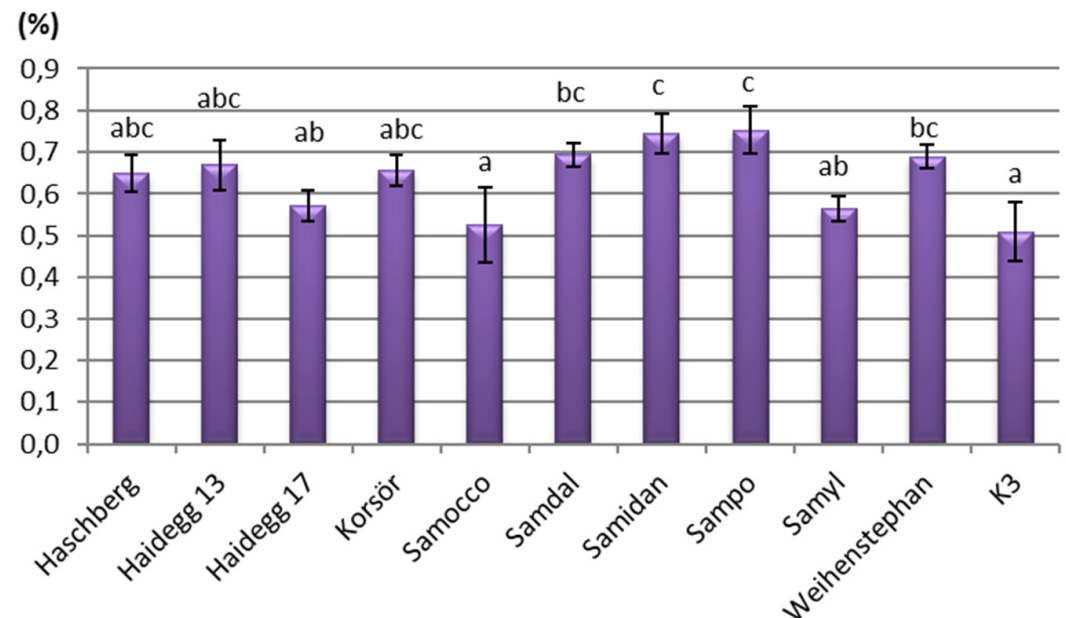

Figure 3. Mean values of titratable acidity in the fruit of different elderberry cultivars. Different letters indicate significant differences between the values (Sidak test, $\mathrm{p}<0.05$ )

\section{Ferric reducing antioxidant power (FRAP)}

Elderberries are a rich source of antioxidants such as phenolic acids, flavonols and anthocyanins (Cejpek et al., 2009). Numerous factors influence the quantity of antioxidant compounds accumulated in the fruit, which also depends greatly on the genotype (Scalzo et al., 2005), as confirmed by the present statistical analysis 
$(\mathrm{F}(10 ; 22)=3.61 ; \mathrm{p}=0.006)$. This was also demonstrated by Hegedüs et al., (2008) for other berry fruit species. The mean FRAP values of the 11 cultivars can be seen in Figure 4. The values found here were slightly higher than those reported by Stéger-Máté et al. (2007). In all three years the cultivar with the highest FRAP value was 'Haidegg 17', followed by 'Haidegg 13' and 'Weihenstephan'. The results of Mlynarczyk et al. (2015), who found that 'Haschberg' had greater antioxidant capacity than 'Sampo' or 'Samyl', were not confirmed in the present study. Matejicek et al. (2015) also reported considerable antioxidant capacity for 'Haschberg', with low values for 'Haidegg 13' and 'Korsör'.

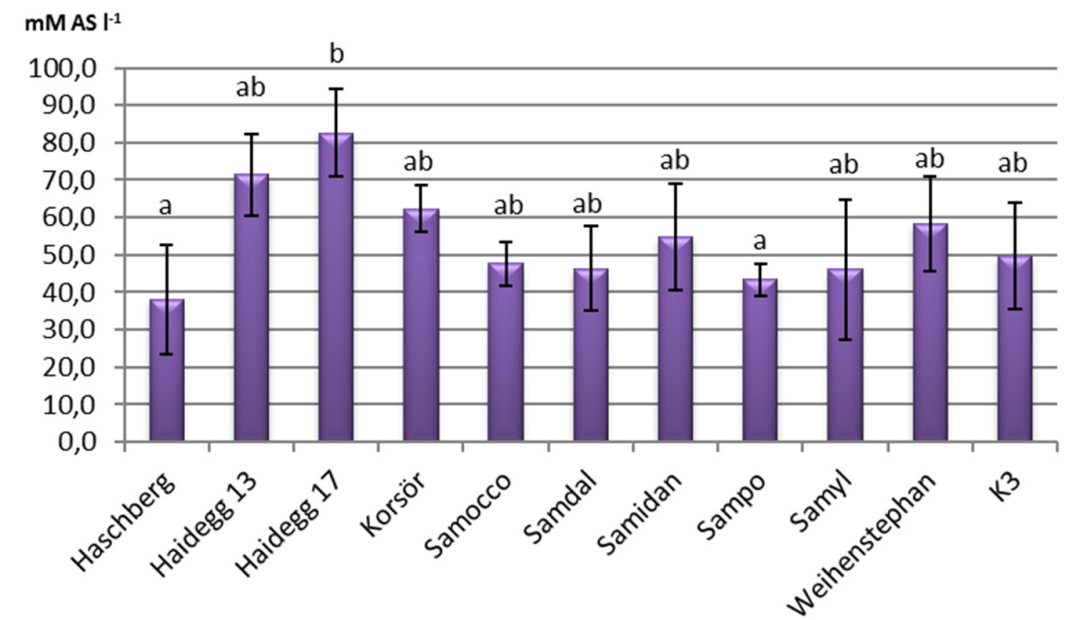

Figure 4. Mean values of antioxidant capacity in the fruit of different elderberry cultivars. Different letters indicate significant differences between the values (Sidak test, $\mathrm{p}<0.05$ )

\section{Total polyphenol content (TPC)}

The mean polyphenol contents of the 11 elderberry cultivars included in the experiment exhibited great variability, as shown in Table 1 . The data were not always in agreement with those published in the literature.

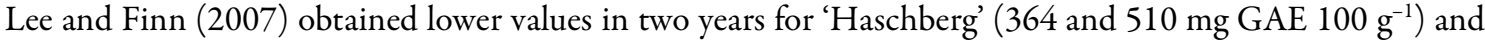
also for 'Korsör' (387 and $\left.582 \mathrm{mg} \mathrm{GAE} 100 \mathrm{~g}^{-1}\right)$, while Ferreria et al. (2020) reported higher values $(820 \pm 45$ and $1476 \pm 282 \mathrm{mg} \mathrm{GAE} 100 \mathrm{~g}^{-1} \mathrm{FW}$ ) for the Portuguese cultivars ('Sabugueiro', 'Sabugueira', 'Bastardeira'), though these values depended not only on the genotype but also on the year. The polyphenol contents reported for elderberries by Wu et al. (2004) were as high as those reported here (1950 mg GAE $100 \mathrm{~g} \mathrm{~g}^{-1} \mathrm{FW}$ ) and were outstanding compared to those of other berry fruit species (red- and blackcurrants, gooseberry).

One-way ANOVA also proved that the genotype had a significant effect on the mean polyphenol content $(\mathrm{F}(10 ; 22)=9.77 ; \mathrm{p}<0.001)$. With the exception of 'Haidegg 17', all the cultivars had higher polyphenol content than 'Haschberg'. The best results were recorded for 'Samyl' and 'Weihenstephan', but 'Korsör', 'Samidan' and 'Samocco' also contained substantial quantities of polyphenol. Earlier studies in Hungary (Szalóki-Dorkó, 2016) gave contradictory results, as the Danish 'Samocco', 'Sampo' and 'Samyl' cultivars were found to have polyphenol contents similar to that of 'Haschberg. Few papers have been published on the polyphenol content of European elderberry cultivars; most research has involved either cultivars derived from Sambucus canadensis L., which is native to America, or wild-growing plants (Özgen et al., 2010; Thomas et al., 2013; Duymus et al., 2014; Wu et al., 2015). 
Table 1. Mean polyphenol and anthocyanin contents in the fruit of elderberry cultivars and the anthocyanin/polyphenol ratio

\begin{tabular}{|c|c|c|c|}
\hline \multirow{2}{*}{ Cultivar } & \multicolumn{2}{|c|}{ Content, as mean \pm S.D. (in mg $100 \mathrm{~g}^{-1} \mathrm{FW}$ ) } & \multirow{2}{*}{ TAC/TPC } \\
\cline { 2 - 3 } & Total polyphenol & Total anthocyanin & 0.55 \\
\hline Haschberg & $1011.11 \pm 376.28 \mathrm{ab}$ & $554.03 \pm 220.01 \mathrm{abcd}$ & 0.59 \\
\hline Haidegg 13 & $1691.85 \pm 248.10 \mathrm{abcde}$ & $1008.06 \pm 84.28 \mathrm{~cd}$ & 0.52 \\
\hline Haidegg 17 & $852.59 \pm 93.76 \mathrm{a}$ & $443.63 \pm 38.67 \mathrm{a}$ & 0.45 \\
\hline Korsör & $1894.81 \pm 464.71 \mathrm{bcde}$ & $856.47 \pm 233.31 \mathrm{abcd}$ & 0.45 \\
\hline Samocco & $1963.70 \pm 371,91 \mathrm{cde}$ & $888.57 \pm 17.25 \mathrm{~cd}$ & 0.56 \\
\hline Samdal & $1431.11 \pm 72.45 \mathrm{abcd}$ & $807.48 \pm 79.38 \mathrm{bcd}$ & 0.43 \\
\hline Samidan & $2015.56 \pm 342.17 \mathrm{de}$ & $861.66 \pm 120.95 \mathrm{abcd}$ & 0.53 \\
\hline Sampo & $1071.85 \pm 281.27 \mathrm{abc}$ & $562.75 \pm 28.99 \mathrm{ab}$ & 0.56 \\
\hline Samyl & $2541.48 \pm 228.10 \mathrm{e}$ & $1413.84 \pm 143.84 \mathrm{~d}$ & 0.46 \\
\hline Weihenstephan & $2142.96 \pm 249.09 \mathrm{de}$ & $990.42 \pm 99.42 \mathrm{bd}$ & 0.46 \\
\hline K3 & $1383.70 \pm 271.08 \mathrm{abcd}$ & $634.74 \pm 123.45 \mathrm{abc}$ & \\
\hline
\end{tabular}

Note: Different letters indicate significant differences between the values (Sidak test, $\mathrm{p}<0.05$ ).

\section{Total anthocyanin content (TAC)}

In addition to soluble solids content, the quantity of anthocyanins present in the fruit is also an important trait, since $90 \%$ of the harvested berries are used by the food industry to produce pigment concentrates (Kaack, 1990; Charlebois et al., 2010). Like the polyphenol content, the anthocyanin content, shown in Table 1, also exhibited considerable differences between the cultivars. The values recorded in the present work differed from some of those found in the literature. Lee and Finn (2007), for example, reported lower values, depending on the year and cultivar (364 and $582 \mathrm{mg} \mathrm{CGE} 100 \mathrm{~g}^{-1} \mathrm{FW}$ ), while higher anthocyanin contents, similar to those found here, were recorded by Veberic et al. (2009) $\left(1265.3 \pm 21.0 \mathrm{mg}\right.$ CGE $100 \mathrm{~g} \mathrm{~g}^{-1}$ FW) and Wu et al. (2004) (1373.4 mg CGE $100 \mathrm{~g}^{-1} \mathrm{FW}$ ).

Statistical analysis also revealed the significant effect of the cultivar on the mean anthocyanin content $(\mathrm{F}(10 ; 8.52)=36.18 ; \mathrm{p}<0.001)$. With the exception of 'Haidegg 17' and 'Sampo', all the cultivars had higher anthocyanin contents than 'Haschberg', as also reported by Kaack and Knudsen (2015). In contrast, Mlynarczyk et al. (2020) detected higher anthocyanin content in 'Haschberg' than in 'Samyl' or 'Sampo'. In the present work the highest value was recorded for 'Samyl', which agrees with the results of Möhler $e t$ al. (2009) and Kaack (1989). On the other hand, outstanding values were found by Szalóki-Dorkó et al. (2015) for 'Samocco', and by Kaack et al. (2008) and Kaack and Austed (1998) for 'Sampo'.

\section{Relationship between chemical parameters}

Pearson's correlation analysis was used to detect statistical relationships between the chemical parameters, taking the results recorded in the individual years as a single data set $(\mathrm{n}=33)$. As also reported by Özgen et al. (2010), a close linear correlation was found between the polyphenol and anthocyanin contents $(\mathrm{r}=0.91, \mathrm{p}<0.001)$.

In the present study the ratio between the polyphenol and anthocyanin contents (TAC/TPC ratio) ranged from 0.43-0.59 (Table 1), in agreement with the values reported by Jakobek et al. (2007) and Wu et al. (2015). In contrast, Szalóki-Dorkó (2016) found a much lower ratio (0.07-0.18), with the highest anthocyanin ratio for 'Haidegg 13' and the lowest for 'Samdal'. The TAC/TPC ratios reported by Lee and Finn (2007) for 'Haschberg' and 'Korsör' were in agreement with those found in the present work.

No other correlations were detected between the chemical parameters. Although phenolic compounds, including anthocyanins, exhibit intense antioxidant activity and many papers have reported that polyphenols and anthocyanins are strongly correlated with antioxidant capacity (Wang and Lin, 2000; Moyer et al., 2002; 
Özgen et al., 2006; Mathieu et al., 2015), this correlation could not be detected for the present data. As also reported by Ramaiya et al. (2012), TPC and TAC were not found to correlate with the FRAP parameter.

\section{Influence of the year on the chemical composition of elderberry}

When examining the effect of the year on the chemical properties of the cultivars, the mean data were evaluated separately for each year $(\mathrm{n}=11)$. The statistical analysis (ANOVA) revealed that the year had a significant effect on SSC $(\mathrm{F}(2 ; 30)=4.02 ; \mathrm{p}=0.028)$ and FRAP $(\mathrm{F}(2 ; 30)=5.21 ; \mathrm{p}=0.011)$ (Table 2), but not on the other parameters (TA: $F(2 ; 30)=1.69 ; \mathrm{p}=0.202$; TPC: $\mathrm{F}(2 ; 30)=0.82 ; \mathrm{p}=0.452$; TAC: $\mathrm{F}(2 ; 30)=1.32$; $\mathrm{p}=0.283)$. Changes in the chemical traits of the fruit in different years were also reported by Lee and Finn (2007), Thomas et al. (2013) and Ferreria et al. (2020).

Table 2. Effect of the year on the mean values of chemical traits in different cultivars

\begin{tabular}{|c|c|c|c|c|c|}
\hline Year & $\begin{array}{l}\text { Soluble solids } \\
\text { content } \\
(\%)\end{array}$ & $\begin{array}{l}\text { Titratable } \\
\text { acidity } \\
(\%)\end{array}$ & $\begin{array}{l}\text { Ferric reducing } \\
\text { antioxidant power } \\
\left(\text { mmol AAE }-^{-1}\right)\end{array}$ & $\begin{array}{l}\text { Total polyphenol } \\
\text { content } \\
\left(\mathrm{mg} \mathrm{GAE} 100 \mathrm{~g}^{-1}\right)\end{array}$ & $\begin{array}{c}\text { Total anthocyanin } \\
\text { content } \\
\left(\mathrm{mg} \mathrm{Cy} 3 \mathrm{G} 100 \mathrm{~g}^{-1}\right)\end{array}$ \\
\hline 2017 & $12.29 \pm 1.19 \mathrm{ab}$ & $0.60 \pm 0.10 \mathrm{a}$ & $60.83 \pm 15.47 b$ & $1740.8 \pm 628,33 \mathrm{a}$ & $895.41 \pm 300.46 a$ \\
\hline 2018 & $12.05 \pm 1.26 \mathrm{a}$ & $0.63 \pm 0.09 \mathrm{a}$ & $43.16 \pm 14.74 \mathrm{a}$ & $1456.96 \pm 598.32 \mathrm{a}$ & $710.46 \pm 281.65 \mathrm{a}$ \\
\hline 2019 & $13.43 \pm 1.19 b$ & $0.67 \pm 0.07 \mathrm{a}$ & $59.88 \pm 13.03 \mathrm{~b}$ & $1711.51 \pm 482.30 \mathrm{a}$ & $854.57 \pm 258.55 \mathrm{a}$ \\
\hline
\end{tabular}

Note: Different letters indicate significant differences between the values (Sidak test, $\mathrm{p}<0.05$ ).

The fact that the soluble solids content of elderberries changed in response to different climatic factors was also demonstrated by the findings of Tolic et al. (2017). The distribution and quantity of rainfall during the ripening period (July and August) was not consistent in any of the years (Table 3). While the monthly precipitation quantity fell on a number of occasions in 2017 and 2019, in 2018 almost the whole quantity fell on three days. In the case of sour cherries, it was observed by Szabó et al. (2010) that greater rainfall quantities during ripening led to a significant drop in the soluble solids content, but this was not confirmed in the present work, since the highest mean SSC value was recorded in 2019, the wettest year. The quantity of rainfall during ripening may also be decisive for the acid content, with higher quantities resulting in greater acid content and lower quantities in reduced acid content, as seen in 2019 (Mills et al., 1996).

Table 3. Mean temperature, diurnal temperature variation and precipitation during July and August (Soroksár) (www. metnet.hu)

\begin{tabular}{|c|c|c|c|c|c|c|}
\hline \multirow{2}{*}{ Year } & \multicolumn{2}{|c|}{$\begin{array}{c}\text { Temperature } \\
\left({ }^{\circ} \mathrm{C}\right)\end{array}$} & $\begin{array}{c}\text { Diurnal temperature variation } \\
\left({ }^{\circ} \mathrm{C}\right)\end{array}$ & \multicolumn{2}{c|}{$\begin{array}{c}\text { Precipitation } \\
(\mathrm{mm})\end{array}$} \\
\cline { 2 - 7 } & July & August & July & August & July & August \\
\hline 2017 & 23.17 & 24.15 & 12.35 & 12.14 & 60 & 57 \\
\hline 2018 & 23.21 & 24.74 & 11.97 & 12.97 & 54.5 & 54 \\
\hline 2019 & 23.03 & 24.26 & 9.08 & 14.99 & 87.8 & 45.1 \\
\hline
\end{tabular}

The mean temperature during ripening was the highest in 2018, with similar lower values in 2017 and 2019. According to Szabó et al. (2010) the fluctuation between day and night temperatures had the greatest influence on the soluble solids content, with larger temperature differences resulting in higher SSC and smaller differences in lower SSC. This was confirmed in the present work, as the highest mean SSC values were recorded in 2019, when the temperature fluctuation was most pronounced.

The antioxidant compounds in the fruit were influenced by the conditions that preceded harvest, the climate, the temperature, the light intensity, the soil type and mineral fertiliser (Wang, 2006). Some researchers found changes in antioxidant capacity in different years (Connor et al., 2002; Goncalves et al., 2007), as in the present work, while this was not observed in other cases (van der Sulis et al., 2001; Bolling et al., 2010). In 
studies on strawberry, Wang and Zheng (2001) concluded that higher temperatures $\left(25-30{ }^{\circ} \mathrm{C}\right)$ resulted in considerably higher antioxidant activity and anthocyanin and polyphenol contents in cultivated fruit, while these values were lower under cooler conditions. However, this was not borne out by the present results, since the highest FRAP, TPC and TAC values were recorded in the two coolest harvesting seasons $(2017,2018)$. According to Remberger $e t$ al. (2014) the quantity of antioxidant compounds in berries depends less on the temperature than on the rainfall. This was confirmed by the present data, as higher FRAP, TPC and TAC values were found in 2017 and 2019, when the rainfall quantity was also greater.

\section{Conclusions}

Due to the end-use of elderberries, the chemical properties of the fruit are just as important as the physical parameters. The present work investigated the effect of cultivar and year on the chemical components of elderberries and the existence of correlations between these components. The results showed that the chemical parameters were determined to a decisive extent by the genotype, though the climatic conditions also influenced annual changes in these properties. A statistical relationship between the chemical traits could only be detected for TPC and TAC. A comparative evaluation of the cultivars led to the conclusion that several cultivars were promising for individual quality traits. 'Haidegg 17 ' had extremely high soluble solids content and antioxidant capacity, while 'Sampo', 'Weihenstephan' and 'Samidan' were outstanding for their polyphenol and anthocyanin contents. The results of this study provide new information on the chemical components of European elderberry cultivars, which could be of use both for the industrial processing of the cultivars and for the selection of new breeding stocks.

\section{Acknowledgements}

This research received no specific grant from any funding agency in the public, commercial, or not-forprofit sectors.

\section{Conflict of Interests}

The authors declare that there are no conflicts of interest related to this article.

\section{References}

Akbulutu M, Ercisli S, Tosun M (2009). Physico-chemical characteristics os fome wild grown European elderberry (Sambucus nigra L.) genotypes. Pharmacognosy Magazine 5:320-323. https://doi.org/10.4103/09731296.58153

Benzie IF, Strain JJ (1996). The ferric reducing ability of plasma (FRAP) as a measure of "antioxidant power": the FRAP assay. Analytical Biochemistry 239(1):70-76. https://doi.org/10.1006/abio.1996.0292

Bolling BW, McKay DL, Blumberg JB (2010). The phytochemical composition and antioxidant actions of tree nuts. Asian Pacific Journal of Clinical Nutrition 19(1):117-123.

Cejpek K, Malousková I, Konecny M, Velísek J (2009). Antioxidant activity in variously prepared elderberry foods and supplements. Czech Journal of Food Sciences 27:45-48. https://doi.org/10.17221/951-cjfs

Charlebois D, Byers PL, Finn CE, Thomas AL (2010). Elderberry: botany, horticulture, potential. Horticultural Reviews 37:213-280. https://doi.org/10.1002/9780470543672.ch4 
Connor AM, Luby JJ, Finn CE, Hancock JF (2002). Genotypic and environmental variation in antioxidant activity among blueberry cultivars. Acta Horticulturae 574:209-213. https://doi.org/10.17660/actahortic.2002.574.31

Csorba V, Fodor M, Kovács Sz, Tóth M (2019). Potential of Fourier transformed near-infrared (FT-NIR) spectroscopy for rapid analysis of elderberry (Sambucus nigra L.) fruits. Czech Journal of Food Sciences 37(1):21-28. https://doi.org/10.17221/144/2018-cjfs

Dobson AJ (2002). An introduction to generalized linear models. (2nd ed). Chapman \& Hall/CRC

Duymus HG, Göger F, Baser KHC (2014). In vitro antioxidant properties and anthocyanin compositions of elderberry extracts. Food Chemistry 155:112-119. https://doi.org/10.1016/j.foodchem.2014.01.028

Fejer J, Salamon I, Grulova D, Michalek S, Zvalova M (2015). Elderberry (Sambucus nigra) cultivation in Slovak Republic and identification and quantification of anthocyanins. Acta Horticulturae 1061:253-258. https://doi.org/10.17660/actahortic.2015.1061.28

Ferreria SS, Silva P, Silva AM, Nunes FM (2020). Effect of harvesting year and elderberry cultivar on the chemical composition and potential bioactivity: A three-year study. Food Chemistry 302:125366. https://doi.org/10.1016/j.foodchem.2019.125366

Füleki T, Francis FJ (1968). Quantitative methods for anthocyanins. II. Determination of total anthocyanin and degradation index for cranberry juice. Journal of Food Science 33:78-83. https://doi.org/10.1111/j.13652621.1968.tb00888.x

Goncalves B, Silva AP, Moutinho-Pereira J, Bacelar E, Rosa E, Meyer AS (2007). Effect of ripeness and postharvest storage on the evolution of colour and anthocyanins in cherries (Prunus avium L.). Food Chemistry 103(3):976-984. https://doi.org/10.1016/j.foodchem.2006.08.039

Hang L (2014). Foundations of applied statistical methods. Springer International Publishing. Switzerland.

Hegedűs A, Balogh E, Engel R, Sipos BZ, Papp J, Blázovics A, Stefanovits-Bányai É (2008). Comparative nutrient element and antioxidant characterization of berry fruit species and cultivars grown in Hungary. American Society of Horticultural Science 43:1711-1715. https://doi.org/10.21273/hortsci.43.6.1711

Jakobek L, Seruga M, Medvidovic-Kosanovic M, Novak I (2007). Anthocyanin content and antioxidant activity of various red fruit juices. Deutsche Lebensmittel-Rundschau 103(2):58-64.

Kaack K (1989). New varieties of elderberry (Sambucus nigra L.). Tidsskrift for Planteavl 93:59-65.

Kaack K (1990). Ripening of elderberry (Sambucus nigra L.). Tidsskrift for Planteavl 94(1):127-129.

Kaack K (1997). 'Sampo' and 'Samdal', elderberry cultivars for juice concentrates. Fruit Varieties Journal 51(1):28-31.

Kaack K, Austed T (1998). Interaction of vitamin C and flavonoids in elderberry (Sambucus nigra L.) during juice processing. Plant Foods for Human Nutrition 52:187-198. https://doi.org/10.1023/A:1008069422202

Kaack K, Christensen LP, Hughes M, Eder R (2005). The relationship between sensory quality and volatile compouds in raw juice processed from elderberries (Sambucus nigra L.). European Food Research and Technology 221:244254. https://doi.org/10.1007/s00217-005-1141-4

Kaack K, Frette XC, Christensen LP, Landbo AK, Meyer AS (2008). Selection of elderberry (Sambucus nigra L.) genotypes best suited for the preparation of juice. European Food Research and Technology 226:843-855. https://doi.org/10.1007/s00217-007-0605-0

Kaack K, Knudsen BF (2015). Horticultural production of flowers and berries of elder (Sambucus nigra) as raw material for processing of foods and pharmaceuticals. Acta Horticulturae 1061:201-208. https://doi.org/10.17660/actahortic.2015.1061.21

Knudsen BF, Kaack K (2015). A review of human health and disease claims for elderberry (Sambucus nigra) fruit. Acta Horticulturae 1061:121-134. https://doi.org/10.17660/actahortic.2015.1061.12

Kollányi L, Kollányi G, Hajdú B (2005). A fekete bodza fajtaválasztékának bővítésére alkalmas fajták és fajtajelöltek. [Cultivars and candidates for the enlargement of elderberry assortment]. In: Tóth M (Eds). Development of variety assortments in the horticulture. Proceedings of selected papers - Lippay János Scientific Conference. 2021, Oct, 2005, Budapest, Hungary pp 83-88.

Lee J, Finn CE (2007). Anthocyanins and other polyphenolics in American elderberry (Sambucus canadensis) and European elderberry (S. nigra) cultivars. Journal of the Science of Food and Agriculture 87:2665-2675. https://doi.org/10.1002/jsfa.3029 
Matejicek A, Kaplan J, Matejickova J, Vespalcova M, Cetkovska J (2015). Comparison of substances in elderberry cultivars and wild elderberry. Acta Horticulturae 1074:105-109. https://doi.org/10.17660/actahortic.2015.1074.15

Mills TM, Behboudian MH, Clothier BE (1996). Preharvest and storage quality of 'Braeburn' apple fruit grown under water deficit conditions. New Zealand Journal of Crop and Horticultural Science 24:159-166. https://doi.org/10.1080/01140671.1996.9513948

Mlynarczyk K, Walkowiak-Tomczak D, Lysiakb GP (2018). Bioactive properties of Sambucus nigra L. as a functional ingredient for food and pharmaceutical industry. Journal of Functional Foods 40:377-390. https://doi.org/10.1016/j.jff.2017.11.025

Mlynarczyk K, Walkowiak-Tomczak D, Staniek H, Kidon M, Lysiak GP (2020). The content of selected minerals, bioactive compounds and the antioxidant properties of the flowers and fruit of selected cultivars and wildly growing plants of Sambucus nigra. https://doi.org/10.20944/preprints202001.0141.v1

Moyer RA, Hummer KE., Finn CE, Frei B, Wrolstad RE (2002). Anthocyanins, phenolics, and antioxidant capacity in diverse small fruits: Vaccinium, Rubus, and Ribes. Journal of Agricultural and Food Chemistry 50(3):519-525. https://doi.org/10.1021/jf011062r

Möhler M, Blaschek W, Lohnwasser E, Walther E (2009). Holunder (Sambucus nigra L.). In: Hoppe B (Eds). Handbuch des Arznei- und Gewürzpflanzenbaus. Grafisches Centrum Cuno, Bernburg, Germany pp 551-561.

Netzel M, Strass G, Herbst M, Dietrich H, Bitsch R, Bitsch I, Frank T (2005). The excretion and biological antioxidant activity of elderberry antioxidants in healthy humans. Food Research International 38:905-910. https://doi.org/10.1016/j.foodres.2005.03.010

Özgen M, Scheerens JC, Reese RN, Miller RA (2010). Total phenolic, anthocyanin contents and antioxidant capacity of selected elderberry (Sambucus canadensis L.) accessions. Pharmacognosy Magazine 6:198-203. https://doi.org/10.4103/0973-1296.66936

Özgen M, Tulio AZ, Chanon AM, Janakiraman N, Reese RN, Miller AR, Scheerens JC (2006). Phytonutrient accumulation and antioxidant capacity at eight developmental stages of black raspberry fruit. American Society for Horticultural Science 41:1082. https://doi.org/10.21273/hortsci.41.4.1082c

Pernkins-Veazie P, Thomas AL, Byers PL, Finn CE (2015). Fruit composition of elderberry (Sambucus spp.) genotypes grown in Oregnon and Missouri, USA. Acta Horticulturae 1061:219-224. https://doi.org/10.17660/actahortic.2015.1061.24

Ramaiya DS, Bujang JS, Zakaria MH, King WS, Shaffiq Sahrir MA (2012). Sugars, ascorbic acid, total phenolic content and total antioxidant activity in passion fruit (Passiflora) cultivars. Journal of the Science of Food and Agriculture 93(5):1198-1205. https://doi.org/10.1002/jsfa.5876

Remberg SF, Wold AB, Sonsteby A, Heide OM (2014). Effects of preharvest factors on berry quality. Acta Horticulturae 1017:181-187. https://doi.org/10.21273/hortsci.30.4.751b

Safránková P (2011). Chemical composition of berries juices from some cultivars of european elder. MSc Dissertation, Brno Univertity of Technology.

Salvador AC, Rocha SM, Silvestre AJD (2015). Lipophilic phytochemicals from elderberries (Sambucus nigra L.): Influence of ripening, cultivar and season. Industrial Crops and Products 71:15-23. https://doi.org/10.1016/j.indcrop.2015.03.082

Scalzo J, Politi A, Pellegrini N, Mezzetti B, Battino M (2005). Plant genotype affects total antioxidant capacity and phenolic contents in fruit. Nutrition 21:207-213. https://doi.org/10.1016/j.nut.2004.03.025

Schmitzer V, Veberic R, Slatnar A, Stampar F (2010). Elderberry (Sambucus nigra L.) Wine: A Product Rich in Health Promoting Compounds. Journal of Agricultural and Food Chemistry 58(18):10143-10146. https://doi.org/10.1021/jf102083s

Sidor A, Gramza-Michałowska A (2015). Advanced research on the antioxidant and health benefit of elderberry (Sambucus nigra) in food - A review Journal of Functional Foods 18:941-958.

Singleton VL, Rossi JA (1965). Colorimetry of total phenolics with phosphomolybdic-phosphotungstic acid reagents. American Journal of Enology and Viticulture 16:144-158. https://doi.org/10.1016/j.jff.2014.07.012

Stefanovits-Bányai É, Schiffler E, Stéger-Máté M, Sipos BZ, Hegedűs A (2004). A feketebodza (Sambucus nigra L.) beltartalmi értékeinek és antioxidáns hatásának változása az érés folyamán. [Chemical composition and antioxidant changes of black elderberry (Sambucus nigra L.) during ripening]. Olaj Szappan Kozmetika 53(1):33-36. 
Stéger-Máté M, Horváth D, Ivanics J, Nótin B, Barta J, Kókai Z, Stefanovitsné Bányai É (2007). Gyümölcsnektárok elóllítása antioxidáns hatású alapanyagokból [Fruit Nectars Manifacturing based on components acting antioxidant]. Alkoholmentes Italok 7(4):59-63.

Stéger-Máté M, Horváth E, Sipos BZ, Ivanics J (2002). A feketebodza (Sambucus nigra L.) összetételének vizsgálata az érés során. [Examination of ingredients of elderberry (Sambucus nigra L.] during ripening) In: Hodúr C, Faragó J, Péter Szabó I, Dani G (Eds). Proceeding of 5th International Conference on Food Science. Szeged, Hungary pp 143-144.

Szabó Z, Lakatos L, Nyéki J, Racskó J, Soltész M (2010). A gyümölcsminőséget befolyásoló fajtatulajdonságok, fiziológiai és klimatológiai tényezők vizsgálata [Examination of cultivar properties, physiological and agroclimatic factors influencing fruit quality parameters]. Retrieved 2020 February 10 from http://real.mtak.hu/2645/1/63065_ZJ1.pdf

Szalóki-Dorkó L (2016). Analytical study of elderberry anhocyanins during food technology. PhD Thesis, Szent István University, Gödöllő.

Szalóki-Dorkó L, Csizmadia Gy, Abrankó L, Stéger-Máté M (2015). Examination of anthocyanin content of some elderberry cultivars grown in Hungary. Acta Horticulturae 1061:79-88. https://doi.org/10.17660/actahortic.2015.1061.7

Thomas AL, Byers PL, Avery Jr. JD, Kaps M, Gu S (2015). Horticultural performance of eight american elderberry genotypes at three Missouri locations. Acta Horticulturae 1061:237-244. https://doi.org/10.17660/actahortic.2015.1061.26

Thomas AL, Pernkins-Veazieb P, Byersc PL, Finn C, Lee J (2013). A comparison of fruit characteristics among diverse elderberry genotypes grown in Missouri and Oregon. Journal of Berry Research 3(3):159-168. https://doi.org/10.3233/jbr-130054

Tiralongo E, Wee SS, Lea RA (2016). Elderberry supplementation reduces cold duration and symptoms in air-travellers: a randomized, double-blind placebo-controlled clinical trial. Nutrients 8:182. https://doi.org/10.3390/nu8040182

Tolic MT, Krbavcic IP, Vujevic P, Milinovic B, Jurcevic IL, Vahcic N (2017). Effects of weather conditions on phenolic content and antioxidant capacity in juice of chokeberries (Aronia melanocarpa L.) Polish Journal of Food and Nutrition Science 67(1):67-74. https://doi.org/10.1515/pifns-2016-0009

van der Sluis AA, Dekker M, de Jager A, Jongen WMF (2001). Activity and concentration of polyphenolic antioxidants in apple: effect of cultivar, harvest year, and storage conditions. Journal of Agricultural and Food Chemistry 49:3606-3613. https://doi.org/10.1021/jfo01493u

Veberic R, Jakopic J, Stampar F, Schmitzer V (2009). European elderberry (Sambucus nigra L.) rich in sugars, organic acids, anthocyanins and selected polyphenols. Food Chemistry 114(2):511-515. https://doi.org/10.1016/j.foodchem.2008.09.080

Vulic JJ, Vracar LO, Sumic ZM (2008). Chemical characteristics of cultivated elderberry fruit. Acta periodica technologica 39:85-90. https://doi.org/10.2298/apt0839085v

Wang SI, Lin HS (2000). Antioxidant activity in fruits and leaves of blackberry, raspberry and strawberry varies with cultivar and developmental stage. Journal of Agricultural and Food Chemistry 48:140-146. https://doi.org/10.1021/jf9908345

Wang SY (2006). Effect of pre-harvest conditions on antioxidant capacity in fruits. Acta Horticulturae 712:299-306. https://doi.org/10.17660/actahortic.2006.712.33

Wang SY, Zheng W (2001). Effect of plant growth temperature on antioxidant capacity in strawberry. Journal of Agricultural and Food Chemistry 49(10):4977-4982. https://doi.org/10.1021/jf0106244

Wissgott U, Bortlik K (1996). Prospects for new natural food colorants. Trends in Food Science and Technology 7(9):298-302. https://doi.org/10.1016/0924-2244(96)20007-x

Wu H, Johnson MC, Lu CH, Fritsche KL, Thomas AL, Cai Z, Greenlief CM (2015). Determination of anthocyanins and total polyphenols in a variety of elderberry juices by UPLC-MS/MS other methods. Acta Horticulturae 1061:43-51. https://doi.org/10.17660/actahortic.2015.1061.3

Wu X, Gu L, Prior RL, McKay S (2004). Characterization of anthocyanins and proanthocyanidins in some cultivars of Ribes, Aronia, and Sambucus and their antioxidant capacity. Journal of Agricultural and Food Chemistry 52(26):7846-7856. https://doi.org/10.1021/jf0486850 
OPEN ACCESS

(c) (i)

The journal offers free, immediate, and unrestricted access to peer-reviewed research and scholarly work. Users are allowed to read, download, copy, distribute, print, search, or link to the full texts of the articles, or use them for any other lawful purpose, without asking prior permission from the publisher or the author.

License - Articles published in Notulae Botanicae Horti Agrobotanici Cluj-Napoca are Open-Access, distributed under the terms and conditions of the Creative Commons Attribution (CC BY 4.0) License. (C) Articles by the authors; UASVM, Cluj-Napoca, Romania. The journal allows the author(s) to hold the copyright/to retain publishing rights without restriction. 